\title{
CORRESPONDENCE
}

\section{GRAVITY MEASUREMENTS OVER THE NORTHERN PENNINES}

SIR,-May I reinforce Professor Holmes's arguments (Geol. Mag., xc, 221-2) for a pre-Carboniferous age for the "Weardale Granite"? The Polygenetic Conglomerate in Limekiln Beck at the northern extremity of the Cross Fell Inlier is crowded with large boulders of granitic rock, so rotten that it is all but impossible to extract them. It seems to me very likely that these have been derived directly from the "Weardale Granite".

Geology Department,

J. Selwyn Turner.

UNIVERSITY OF LEEDS.

4th June, 1953.

SiRS,-The two complementary papers in your April-May, 1953, issue, on gravity measurements over the Alston Block, are of great interest. Few will quarrel with the main inference that the pronounced gravity "low" is due to an acid igneous intrusion.

In itself the anomaly affords no evidence of the age of the intrusion. It is not unreasonable to suggest that it may be linked with the Alston Block mineralization. Nevertheless one is warned to be cautious by Rastall's suggestion that this mineralization is connected with the intrusion of the Whin Sill - a proposition that is demonstrably incorrect. There has been, indeed, much speculation, and in this connection a quotation in Hospers and Wilmore's paper from Wells and Kirkaldy's Outline of Historical Geology (1948) cannot be allowed to remain unchallenged. It reads as follows:-

"As the lodes of the Alston Block cut the Carboniferous, chiefly Yore-

dale, rocks and as many of the ore minerals occur as detrital grains in the basal Permian sediments, the hidden parent granite and the lodes must be Armorican."

Now the basal Permian sediments adjoin both the eastern and the western margins of the Alston Block; but to the west, in Edenside, the basal Penrith Sandstone and its Brockrams yield little or no evidence that is critical, since the included pebbles indicate derivation from three different sources, the Lake District, the Alston Block, and the Howgill Fells. Thus the only recorded occurrence of detrital fluorite, from the Penrith Sandstone of Beulah Beck, does not afford evidence of derivation from the mineral veins of the Alston Block; it occurs, significantly, not far from the outcrop of the Shap Granite of the Lake District and this granite and its associated mineralization (which includes fluorite) is of pre-Carboniferous age.

To the east the basal Yellow Sands of the Permian flank, in County Durham, the full eastern margin of the Alston Block. If fluorite or barium minerals, or the sulphide ores of zinc, lead, or copper were found in these basal Permians as detritals, then the occurrences would afford evidence in favour of an Armorican age for the Alston Block mineralization; but this is not the case. On the contrary, the detrital heavy minerals of the Yellow Sands of County Durham were found by Hodge to contain none of these ores, not even the ubiquitous detrital barite, although pebbles of Carboniferous limestone-withchert showed that rocks as low as the Yoredales had been exposed to denudation.

As, however, the minerals fluorite, barite, galena, and sphalerite occur, albeit somewhat sparingly, in vugs, as veinlets and lining joints in the Magnesian Limestone, the reasonable inference is that the mineralization commenced in post-Permian times.

Supporting evidence is afforded by strong barium chloride solutions, first described by Mr. W. Anderson and existing in quantity at depths below 1,000 feet B.O.D. in parts of the Durham coalfield, which in places react 
with ground waters to deposit barium minerals-surely the end phase of the Alston Block mineralization.

If we were to link the inferred acid igneous intrusion with the mineralization then the relative paucity of the ore occurrences in the Magnesian Limestone would be explained by the situation of the outcrop of that formation well outside and to the east of the pronounced gravity "low".

\section{Sandileigh Avenue, DIDSBURY, MANCHESTER, 20. \\ 8th June, 1953.}

F. M. TrotTER.

\section{REVIEWS}

The Dynamics of Faulting and Dyke Formation with Applications to Britain. By E. M. Anderson. Second edition revised. Pp. $x+206$, with 39 Text-figs. Oliver and Boyd, Edinburgh, 1951. Price 22s. $6 d$.

Structural Geology. By M. P. Billings. Eighth printing. Pp. xi +473 , with 336 figs. (including several exercises to be torn out), and 19 halftone plates. Sir Isaac Pitman and Sons, Ltd., London (Prentice Hall, Inc., New York), 1952. Price 50s.

Outlines of Structural Geology. By E. Sherbon Hills. Third edition revised. Pp. xi +182 , with 107 text-figs. and 4 half-tone plates. Methuen and Co., Ltd. Price 12s. 6 d.

Structural and Field Geology. By James Geikie. Sixth edition revised (as was the fifth) by $R$. Camprell and R. Craig. Pp. xxiv +397 , with 148 text-figs. and 69 half-tone or coloured plates. Oliver and Boyd, Edinburgh. Price 37s. $6 \mathrm{~d}$.

Four well-known works have all recently reappeared in new dress, and to anticipate this review all four are welcomed and deserve to continue in some form or other.

The third edition of Outlines of Structural Geology (first published in 1940) has been revised throughout both text and figures, and many later references have been added. The value of this work still lies in its concise treatment of essentials. An extensive review of recent literature has been made and this can readily be followed through the generous footnotes. This tends to give the impression that the work has been compiled from books rather than rocks. It is most evident in the only chapter which has been fundamentally expanded. In treating " Major Crustal Structures" Hills collects some of the fashionable theories without much critical analysis. His stimulating treatment of tectonic patterns suffers from a confusion of structures known in detail with structural interpretations popularized in diagrams. Incidentally he favours the tetrahedral hypothesis as a starting-point. At the other end of the scale one might hope that another edition would balance the chapter on petrofabric analysis by one on the similar analysis of the orientation of structures observed in the field. These comments are only prompted by the very high standard which the work as a whole maintains. It is assured of continued popularity.

"Structural Geology," which has changed its colour with successive impressions, is once more reprinted with no other obvious difference than a new title page bearing the name of a London publisher. The quality of paper again hardly does justice to the half-tone illustrations but this is preferable to filling the whole book with kaolin. That the original 1942 version still stands as one of the leading textbooks in this competitive field is a tribute to the clarity of exposition and drawing. Billings's treatment is altogether more 